\title{
Assessing the Risk of Orthorexia in Dietetic and Physiotherapy Students Using the BOT (Bratman Test for Orthorexia)
}

Ocena ryzyka ortoreksji wśród studentów dietetyki i fizjoterapii z użyciem BOT (Bratman Test for Orthorexia)

\author{
${ }^{1}$ Anna Dittfeld, ${ }^{2}$ Katarzyna Gwizdek, ${ }^{3}$ Aneta Koszowska, ${ }^{3}$ Justyna Nowak, ${ }^{3}$ Anna Brończyk-Puzoń, \\ ${ }^{4}$ Paweł Jagielski, ${ }^{5}$ Joanna Oświęcimska, ${ }^{5}$ Katarzyna Ziora
}

${ }^{1}$ Department of Histology and Embryology, School of Medicine with the Division of Dentistry in Zabrze, Medical University of Silesia, Katowice, Poland, '2Department of Physiotherapy, Chair of Physiotherapy, School of Health Sciences in Katowice, Medical University of Silesia, Katowice, Poland, ${ }^{3}$ Department of Food Related Diseases Prevention, School of Public Health in Bytom, Medical University of Silesia, Katowice, Poland, ${ }^{4} \mathrm{Hu}-$ man Nutrition Department, Faculty of Health Science, Jagiellonian University Medical College in Cracov, ${ }^{5}$ Department of Paediatrics in Zabrze, School of Medicine with the Division of Dentistry in Zabrze, Medical University of Silesia, Katowice, Poland

${ }^{1}$ Katedra i Zakład Histologii i Embriologii, Wydział Lekarski z Oddziałem Lekarsko-Dentystycznym w Zabrzu, Śląski Uniwersytet Medyczny w Katowicach, '2Zakład Fizjoterapii, Katedra Fizjoterapii, Wydział Nauk o Zdrowiu, Śląski Uniwersytet Medyczny w Katowicach, ${ }^{3}$ Zakład Chorób Dietozależnych, Wydział Zdrowia Publicznego w Bytomiu, Śląski Uniwersytet Medyczny w Katowicach, ${ }^{4}$ Zakład Żywienia Człowieka, Wydział Nauk o Zdrowiu, Collegium Medicum, Uniwersytet Jagielloński, ${ }^{5}$ Katedra i Klinika Pediatrii w Zabrzu, Wydział Lekarski z Oddziałem Lekarsko-Dentystycznym w Zabrzu, Śląski Uniwersytet Medyczny w Katowicach

\begin{abstract}
Introduction. Orthorexia nervosa is an obsessive-compulsive focus on a "healthy" diet, which manifests as extreme concern about food content. This research was carried out in order to identify highly sensitive behaviours associated with eating a healthy diet. Aim. Assessment of risk of orthorexia nervosa among dietetics students compared to physiotherapy students. Material and Methods. Presented research was conducted among 229 dietetic students and 201 physiotherapy students. It was based on general personal characteristics, the Bratman Test for Orthorexia (BOT) and questions posed by the authors. Results. 26.6\% of the dietetics students and only $14.9 \%$ of physiotherapy students were recognised as health food fanatics. The students of both dietetics (88.2\%) and physiotherapy (52\%) declared that they noticed changes in their attitude towards food after they had become students. Conclusions. It has been observed that these highly sensitive behaviours towards healthy eating are very common in both surveyed groups, however with a stronger tendency among the students of dietetics.
\end{abstract}

Key words:

orthorexia nervosa, students, eating disorders, dietetics, physiotherapy

\section{Streszczenie}

Wstęp. Ortoreksja jest obsesyjno-kompulsywnym zaburzeniem dotyczącym zdrowego sposobu odżywiania. Osoba borykająca się z ortoreksją skupiona jest na komponowaniu diety prozdrowotnej. Osoba taka spożywa jedynie żywność spełniającą jej wyśrubowane kryteria i unika pokarmów potencjalnie szkodliwych. Cel. Ocena ryzyka ortoreksji wśród studentów dietetyki w porównaniu do studentów fizjoterapii. Materiał i metody. Przedstawione badania zostały przeprowadzone wśród 229 studentów dietetyki oraz 201 studentów fizjoterapii. Ankieta została oparta o ogólną charakterystykę osób badanych, test Bratmana (BOT) oraz pytania autorskie. Wyniki. 26,6 \% studentów dietetyki i tylko 14,9\% studentów fizjoterapii uzyskało wynik charakterystyczny dla fanatyków zdrowego żywienia. Zarówno studenci dietetyki (88,2\%), jak i fizjoterapii (52\%) zadeklarowali zmianę w podejściu do żywności po rozpoczęciu 
studiów. Wnioski. W obu grupach zaobserwowano wysoki poziom troski o zdrowe odżywianie. Jednakże większą predyspozyję do ortoreksji wykazują studenci dietetyki.

Słowa kluczowe:

ortoreksja, studenci, zaburzenia odżywiania, dietetyka, fizjoterapia

\section{Introduction}

Orthorexia nervosa $(\mathrm{ON})$ is a new kind of eating disorder [1]. This term comes from Greek words orthos (proper, straight) and orexia (appetite) [2-4]. It is an obsessive-compulsive focus on a "healthy" diet which manifests as an extreme concern about food content $[5,6]$. The first coverage was presented by Steven Bratman in the October issue of Yoga Journal in 1997 [7]. This physician also wrote a book entitled Health Food Junkies that describes the problem of orthorexia [7]. It inspired other physicians and scientists. Orthorexia nervosa (ON), like other eating disorders, is initially harmless in most cases, and even highly desirable [8].

Orthorexic patients initially want to either improve their health status or treat a particular disease [4]. They are bothered by the quality of food rather than quantity $[9,10]$. In addition, these affected individuals tend to exclude from their diet foods which they consider to be impure because of herbicides, pesticides, genetically modified ingredients, and artificial substances $[3,4]$. They also worry in excess about techniques and materials used in food elaboration [4]. Moreover, orthorexics spend a lot of time preparing healthy and pure meals $[1,3,11]$. Any dietary mistakes may sometimes lead to self-derogation and self-punishment [7].

This obsession may result in strict diets with a shortage of essential nutrients $[6,9]$. Orthorexia may either overlap with obsessive-compulsive disorder (OCD) or be a subtype of OCD. The reason for this, as already mentioned, is that orthorexia comes with time-consuming obsessions, e.g. thinking about maintaining a "correct" diet and detailed planning of the menu, as well as compulsions, such as spending a huge amount of time preparing, selecting and eating healthy meals [2]. Nevertheless, it is not clear whether their obsessive thoughts are the cause of distress. It could instead be a compulsive behaviour used to reduce distress and/or prevent potentially catastrophic events, which is a requirement for diagnosing OCD. Moreover, it is important to note that people with orthorexia tend to be smug and self-satisfied with their extreme focus on eating "proper" food, and they sometimes try to propagate their way of thinking [2].

An extremely strict diet may lead to malnutrition and weight loss as in anorexia nervosa [7]. Individuals who suffer from orthorexia refuse to eat out, avoid social events and distance themselves from other people [4]. They can become alienated from their relatives and friends since they tend to be extremely preoccupied with food, associate food choices with virtue, eat only food products which seem both healthy and pure, as well as judge others by their food choices. Therefore, orthorexics frequently experience social isolation and feel guilty if they fail to follow their diet obediently $[3,12]$. Also, according to a spiritual and religious belief, a perfect diet can help achieve purity [7] Although there is a lack of epidemiological data, it is estimated that $0.5-1 \%$ of the population suffer from orthorexia [13]. Scientists suggest that this disease affects women and men equally $[13,14]$. However, other studies show that this disorder can be more specific for either women $[7,15]$ or men [16]. Orthorexia nervosa often affects vegetarians, frugivores (fruitarians) and crudivores (raw food eaters) [4]. Other individuals who may be prone to develop this disorder are those with intense physical activity, increased BMI, higher education, and other eating disorders and/or obsessive-compulsive behaviours $[7,13,15]$. The vogue for both slimness and muscularity increases the number of orthorexics $[14,15]$.

Orthorexia nervosa lacks valid diagnostic criteria. Scientists hesitate whether to classify it as a new type of eating disorder, or just a new eating behaviour. ON has not been officially recognised as a disease, nor has it been classified as an independent entity in the DSM-IV or DSM-V diagnostic criteria $[4,17]$

There are no unique criteria to recognise orthorexia nervosa. In recent studies, scientists have been using mostly two tests: the BOT and the ORTO-15. The BOT will be described in the material and methods paragraph. The ORTO-15 consists of 15 questions concerning the selection, acquisition, preparation and consumption of food [3]

There is no unique therapy recommended for orthorexic patients. However, cognitive behavioural therapy combined with SSRIs may be helpful [7]. Moreover, researchers have found that olanzapine treatment can also be successful [18]. More and more people are trying to meet healthy eating expectations, but when they put too much emphasis on a diet, it can cause the disease. The main problem of both nutritionists and doctors is that they are frequently not aware of disorders, such as orthorexia.

\section{Aim of the study}

Assessment of risk of orthorexia nervosa among dietetics students compared to physiotherapy students.

\section{Materials and methods}

People who pay too much attention to a healthy diet, biological purity and uncontaminated food can be in danger of a new eating disorder - orthorexia. This research was carried out in order to identify highly sensitive behaviours associated with eating a healthy diet. 
The study was conducted among 229 dietetic students and 201 physiotherapy students of the Medical University of Silesia in Katowice, Poland. The research questionnaire was filled in by the students during their lectures and was analyzed by the authors of this article. The aim of the research was to evaluate the risk of orthorexia in the students using the Bratman Test for Orthorexia (BOT). The test was graded and verified according to the authors' guidelines. Additionally, the authors created their own questionnaire to evaluate the students' attitude towards food and nutrition.

The first part of the research was based on general personal characteristics of the surveyed groups such as: age, gender, weight, height, a field of study, and BMI. Self-report measures were used to determine the height and weight of each study participant. The BMI score was calculated and the results were classified according to the WHO (World Health Organisation) classification. Following the WHO criteria, subjects with BMI $<18.5$ were classified as underweight, between 18.5-24.99 as normal weight, and $\geq 25$ as overweight and obese [19].

In the second part of the research,the BOT (Bratman Test for Orthorexia) created by Steven Bratman was utilized. It consists of ten dichotomous items with YES/NO answers. One point is given for every positive answer. Subjects who obtain fewer than
5 points are classified as healthy, 5-9 points as health fanatics, and those who obtain 10 points are considered to suffer from orthorexia nervosa [15].

The third part of the research consisted of the authors' questionnaire in order to evaluate the students' attitude towards food and nutrition, including self-perception.

The results of the research were analyzed by the Anova, the U Mann-Whitney test and the Pearson's chi square test using the STATISTICA 10 Software. The accepted level of statistical significance was at $\alpha<0.05$. The BMI score was calculated on the basis of the participants' weight and height $\left(\mathrm{kg} / \mathrm{m}^{2}\right)$.

\section{Results}

The mean age of the dietetic students was $21.5 \pm 1.6$ years and of the physiotherapy students $20.9 \pm 1.5$ years. The BMl score was calculated and classified according to the WHO criteria. With regard to the dietetic students, the average BMI was $21.1 \pm 2.6 \mathrm{~kg} / \mathrm{m}^{2}$, and for the physiotherapy students, it was $21.5 \pm 2.7 \mathrm{~kg} / \mathrm{m}^{2}$ (table I). The majority of the respondents were women, i.e. $95.2 \%$ of dietetic students and $87.1 \%$ of physiotherapy students. Statistical significance was observed with

Table I. Anthropometric characteristics of the study groups Tabela I. Charakterystyka antropometryczna badanej grupy

Dietetics

Physiotherapy

\begin{tabular}{lcccccccccccccc}
\hline & $N$ & Mean & SD & Median & Min & Max & $N$ & Mean & SD & Median & Min & Max & $p$ value* \\
\hline age & 228 & 21,5 & 1,6 & 21,0 & 18,0 & 26,0 & 201 & 20,9 & 1,5 & 21,0 & 18,0 & 26,0 & $p<0,0001$ \\
\hline weight & 229 & 58,8 & 8,6 & 58,0 & 32,0 & 86,0 & 201 & 61,3 & 11,1 & 60,0 & 38,0 & 120,0 & 0,0097 \\
\hline hight & 229 & 167,0 & 7,1 & 168,0 & 138,0 & 191,0 & 201 & 168,5 & 7,8 & 168,0 & 152,0 & 195,0 & 0,0350 \\
\hline BMl & 229 & 21,1 & 2,6 & 20,8 & 12,2 & 30,1 & 201 & 21,5 & 2,7 & 21,1 & 15,9 & 31,6 & 0,1145 \\
\hline
\end{tabular}

*U'Mann Whitney test

Table II. Characteristics of the study groups of students according to sex and BMI classification

Tabela II. Charakterystyka badanej grupy z podziałem na płeć oraz BMI

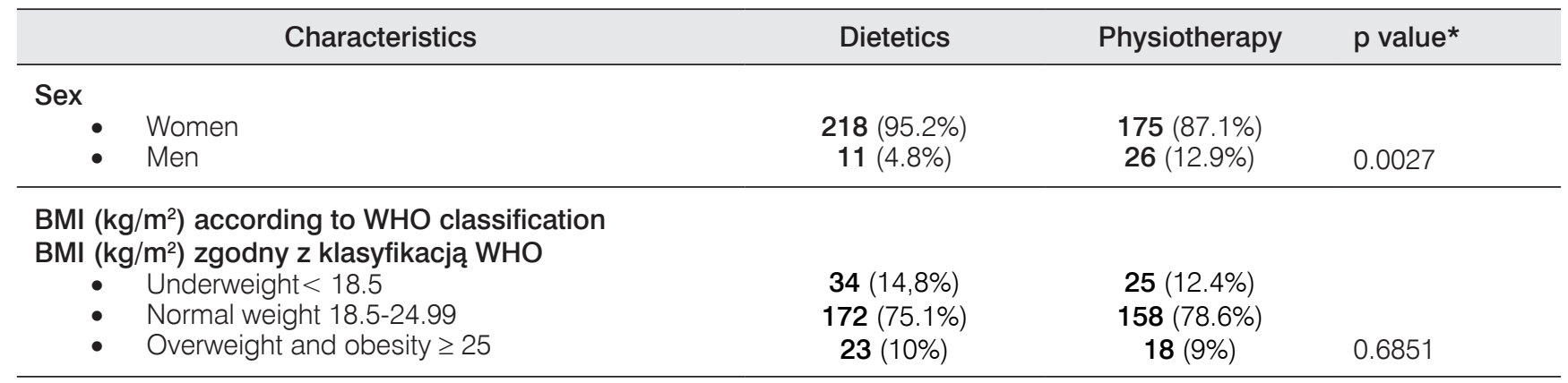


regard to sex $(p=0.0027)$. The physiotherapy group was found to comprise a higher number of men (12.9\% vs. $4.8 \%$ ) (table II).

The analysis of the sample showed that $75.1 \%$ of the dietetics students and $78.6 \%$ of the physiotherapy students had normal body weight. There was no statistically significant difference between the two groups of students nor their BMI (table II).

\section{The BOT results of both surveyed groups with regard to the field of study}

A statistically significant difference was revealed in the BOT results with regard to the field of study, namely $26.6 \%$ of the dietetics students were recognised as health food fanatics, whereas only $14.9 \%$ of the physiotherapy students obtained the same result (Fig. 1).

\section{The BOT results of both surveyed groups with regard to $B M I$}

The ANOVA test showed no statistical significance between either the BOT results or the BMI results in the whole group of 430 students, nor in the group of the physiotherapy students. Minor statistical significance was found in the group of the dietetic students $(p=0.04)$, which makes the result questionable. The results are presented in Fig. 2, 3 and 4.

\section{The results of the authors' questionnaire}

A predominant number of the dietetics students (88.2\%) and $52 \%$ of physiotherapy students declared that they noticed some changes in their attitude towards food after they had become students. A statistically significant difference was observed between both groups $(p<0.05)$. Additionally, a number of the dietetics students $(45.4 \%)$ who declared that their knowledge of food and nutrition made them feel better than the rest of the population was higher when compared to the physiotherapy students (23.4\%). A statistically significant difference $(p<0.05)$ was observed between both study groups.

Having a meal is a ritual for orthorexics. Therefore, they tend to avoid restaurants. If a situation arises that they have to go to

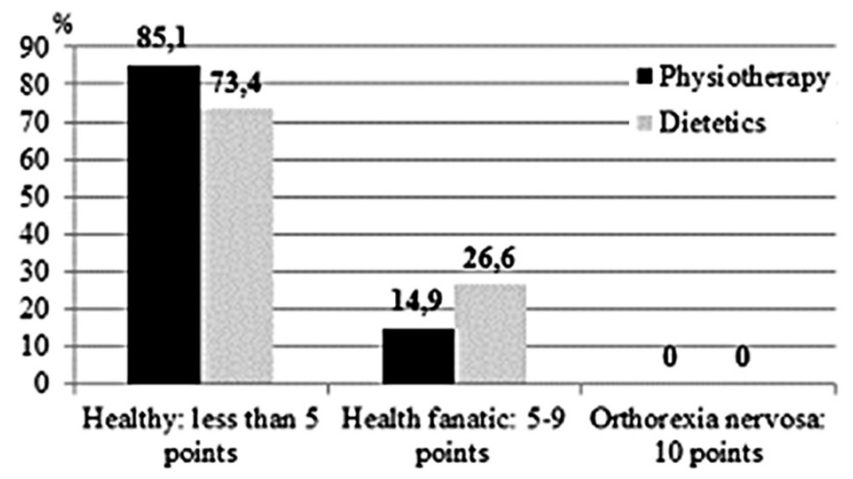

Fig. 1. The results of BOT test among the surveyed groups of students $(p=0.0030)$

Ryc. 1. Wyniki testu BOT wśród badanych grup studentów $(p=0.0030)$

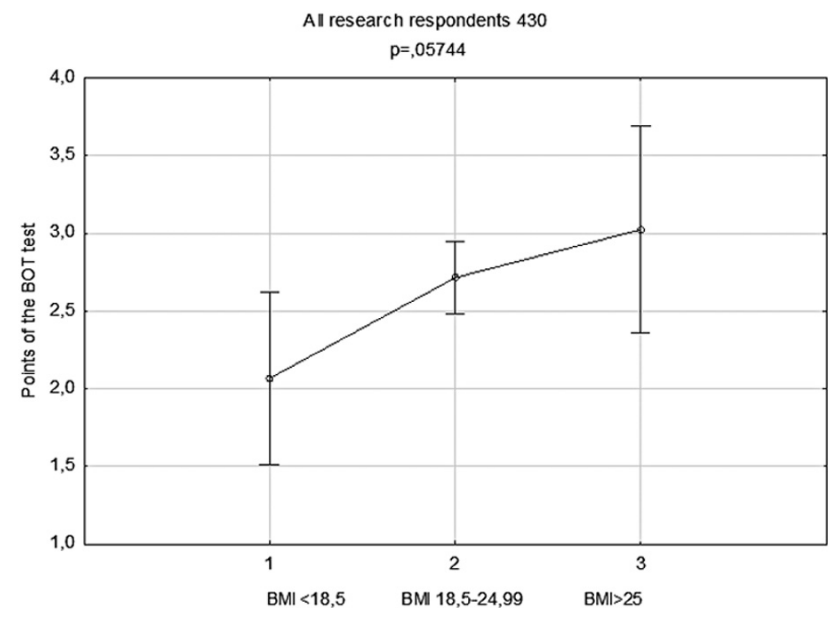

Fig. 2. The results of Bratman test according BMI among all researched students

Ryc. 2. Wyniki testu Bratmana w odniesieniu do BMI wśród badanych studentów

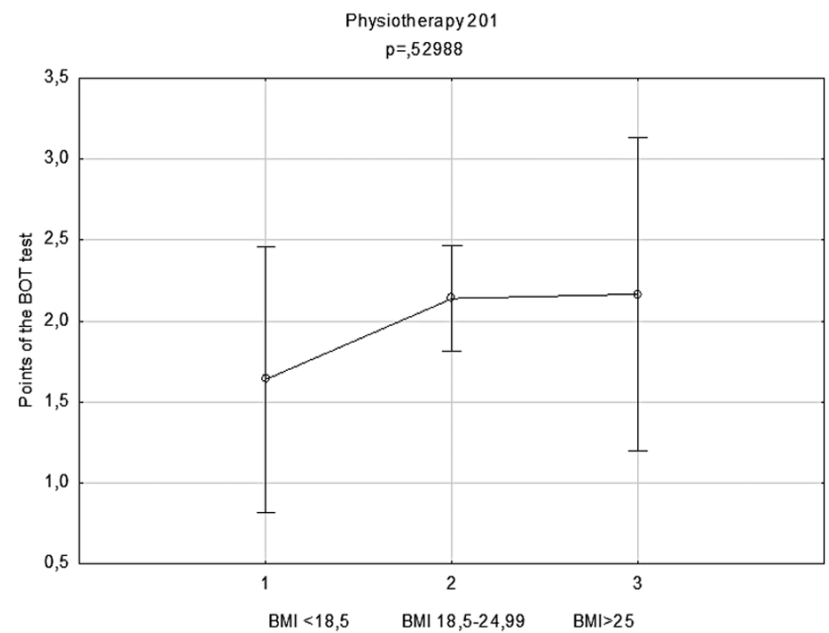

Fig. 3. The results of Bratman test according BMI among Physiotherapy students

Ryc. 3. Wyniki testu Bratmana w odniesieniu do BMI w grupie studentów fizjoterapii

this kind of place, they often bring their own meals [11]. In our research, we asked the students of both fields of study about problems with ordering meals in restaurants. However, no statistical difference was found between the study groups. Also, the students did not notice any differences in their approach to fast food restaurants. In this case, no statistically significant difference was revealed between the study groups either. However, as much as $45.41 \%$ of the dietetics students claimed that they always checked food labels versus $16.9 \%$ of the physiotherapy 


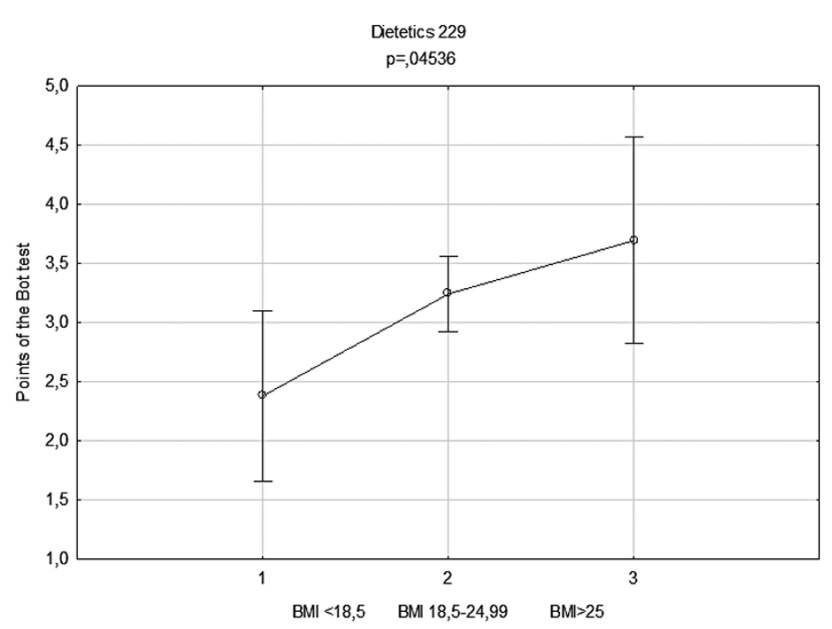

Fig. 4. The results of Bratman test according BMI among Dietetic students

Ryc. 4. Wyniki testu Bratmana w odniesieniu do BMI w grupie studentów dietetyki

students. Thus, a statistically significant difference $(p<0.05)$ between both groups was observed. The students of dietetics declared that the chosen field of study was the reason why they changed their attitude towards food. This resulted in a statistically significant difference of $p<0.05$ between the groups. Moreover, the dietetics students more frequently claimed that they had been interested in food and nutrition before they started their studies, compared to the physiotherapy students. No statistical relationship was observed between the surveyed groups when asked whether anybody had ever suggested that their attitude towards food was pathological. A similar result was obtained in the case of the question concerning the students' attitude towards food - neither group showed any concern.

Additionally, there were no statistically significant differences among the students concerning problems with either mental disorders or eating disorders. Namely, $1.7 \%$ of the dietetics students and $0.5 \%$ of the physiotherapy students admitted that they had been diagnosed with either a mental or eating disorder. None of the groups revealed statistically significant differences when it comes to fear of genetically modified food. Detailed results are presented in Table III.

Based on the results, the students of dietetics have a twofold higher chance of becoming health fanatics when compared to the students of physiotherapy. The odds ratio is: OR $=2.07(\mathrm{Cl} 95 \%=1.24-3.49)$.

\section{Discussion}

It has been observed that highly sensitive behaviours towards healthy eating are very common in both surveyed groups, however with a higher tendency among the students of dietetics. The first studythat looked at the prevalence of orthorexia was published in 2001 by Donini et al. who created the ORTO 15 test and carried out studies among 404 adults. They used the ORTO 15 and showed that orthorexia affected $6.9 \%$ of subjects, mostly men and people with higher education [20]. Other studies conducted in Turkey in 2007 revealed that $45.5 \%$ of 318 studied residents of medicine manifested symptoms typical of orthorexia. The authors used the ORTO 15 test. There were no statistical differences between men nor women [14]. In our research, $4.7 \%$ of the dietetics students and $3.9 \%$ of the physiotherapy students declared that they had been diagnosed with either a psychological disease or eating disorder. In another study that involved only dieticians, $4.6 \%$ of subjects reported that they had been diagnosed with an eating disorder, either anorexia nervosa (3.5\%) or bulimia nervosa (1.1\%) [10]. In the same study, orthorexia self-assessment with the BOT showed the following results: no orthorexia in $52.3 \%$ of subjects, some orthorexic behaviour in $34.9 \%$ of participants, orthorexia in $12.8 \%$ of patients [10]. The results of our study that involved a group of 235 students of dietetics were: no orthorexia in $74 \%$ of students, health food fanaticism in $26 \%$ of subjects, orthorexia in $0 \%$ of participants. The students of dietetics receive an in-depth knowledge of food and nutrition during their studies. Therefore, these students may be particularly prone to manifest disordered eating patterns. Also, it could be a motivating factor for them to choose this field of study. At the same time, an increasing knowledge about food and nutrition could be associated with a tendency to either exhibit a more healthy eating behaviour or develop an unhealthy obsession with food [13]. In another research conducted among the students of nutrition sciences at German universities and the controls not attending nutrition-related studies, the researchers used the following questionnaires: the Eating Behaviour Questionnaire - the German adaptation of the Three Factor Eating Questionnaire (TFEQ), and the German translation of the Bratman test. It was observed that the nutrition students showed a higher degree of restraint. Orthorexic tendencies were lower in the group of more advanced nutrition students. The control group showed slightly more unhealthy food choices than the students of nutrition sciences. The nutrition students were more prone to restrict food intake in order to control their body weight. However, their eating patterns were not more disturbed nor disordered than those of the control group. Moreover, it was observed that during their studies, a tendency to become obsessed with food decreased [13].

As it was shown in the discussion, the estimated prevalence of orthorexia nervosa among medical professionals is high, i.e. 45.5\% (Bagci Bosi, Turkey, 2007) and 6.9\% (Donini 2006). Another research was conducted among 364 registered dieticians in Brazil in 2012. They were graduates of 70 different institutions. The authors claim that if they had adopted the cutoff points accordingly, $81.9 \%$ of Brazilian dieticians could have been classified as orthorexics. Thus, the results of this study show that the ORTO-15 may not be an appropriate instrument to evaluate orthorexic behaviour for every country. On the other hand, Brazilian dieticians frequently provided the answers that indicated a tendency towards orthorexia [3]. 
Table III. Table with the results of authors' questions in $\%$ and $p$ value of $\chi^{2}$ test

Tabela III. Wyniki autorskich pytań z uwzględnieniem \%, wartości p oraz testu $\chi 2$

\begin{tabular}{|c|c|c|c|}
\hline Answers & Dietetics Faculty \% & Physiotherapy \% Faculty & $p$ value \\
\hline \multicolumn{4}{|c|}{$\begin{array}{l}\text { Did you notice changes in your attitude towards food?/ Czy zauważył/a Pan/ Pani zmiany w swoim podejściu do } \\
\text { żywności? }\end{array}$} \\
\hline $\begin{array}{l}\text { Yes / tak } \\
\text { No / nie }\end{array}$ & $\begin{array}{l}88.2 \\
11.8\end{array}$ & $\begin{array}{l}52.0 \\
48.0\end{array}$ & $\mathrm{p}<0.0001$ \\
\hline \multicolumn{4}{|c|}{$\begin{array}{l}\text { Do you feel better than the rest of the population with your knowledge of the food outlet?/ Czy czuje się Pan/ Pani } \\
\text { „lepsza” od reszty populacji mając wiedzę o żywności? }\end{array}$} \\
\hline $\begin{array}{l}\text { Yes / tak } \\
\text { No / nie }\end{array}$ & $\begin{array}{l}45,4 \\
54,6\end{array}$ & $\begin{array}{l}23.4 \\
76.6\end{array}$ & $\mathrm{p}<0.0001$ \\
\hline \multicolumn{4}{|c|}{$\begin{array}{l}\text { Have you changed your attitude towards fast food restaurants?/ Czy zmienit/a Pan/ Pani podejście do restauracji typu } \\
\text { Fast food? }\end{array}$} \\
\hline $\begin{array}{l}\text { Yes, I avoid this type of restaurants/ tak, } \\
\text { unikam ich } \\
\text { No, sometimes I visit these places / nie, } \\
\text { czasami je odwiedzam } \\
\text { They are indifferent to me / są mi } \\
\text { obojętne }\end{array}$ & 47.2 & 16.4 & $p=0,2165$ \\
\hline
\end{tabular}

Do you check the label before you buy food product?/ Czy zanim Pan/ Pani zakupi produkt spożywczy analizuje Pan/ Pani etykietę?

\begin{tabular}{llll}
\hline Yes, always / tak, zawsze & 45,4 & 16.9 & \\
I never read the label/ nigdy & 3.5 & 16.4 & $\mathbf{p}<0.0001$ \\
Sometimes / czasami & 51,1 & 66,7 & \\
\hline
\end{tabular}

Do you have problems with ordering food in restaurants?/ Czy ma Pan/ Pani problem z zamawianiem produktów w restauracjach?

\begin{tabular}{|c|c|c|c|}
\hline $\begin{array}{l}\text { Yes, I can't find anything for myself / } \\
\text { tak, nie potrafię znaleźć niczego dla } \\
\text { siebie }\end{array}$ & 11.9 & 8.5 & \\
\hline $\begin{array}{l}\text { No, there is always something for me / } \\
\text { Nie, zawsze jest coś dla mnie }\end{array}$ & 47,8 & 49,2 & $\mathrm{p}=0,4942$ \\
\hline $\begin{array}{l}\text { Sometimes I have a problem/ Czasami } \\
\text { mam problem }\end{array}$ & 40,3 & 42.3 & \\
\hline
\end{tabular}

Did your field of study change your attitude towards food and nutrition? / Czy kierunek studiów zmienił pani postawy wobec żywności?

\begin{tabular}{llll}
\hline Yes, very much / Tak, bardzo & 50.2 & 8,0 & \\
A little / troche & 45.4 & 50.2 & \\
Not at all / Nie & 2.2 & 31.8 & $\mathbf{p}<0.0001$ \\
I don't know / nie wiem & 2.2 & 10.0 & \\
\hline
\end{tabular}

Had you been interested in food and nutrition before you started your studies? / Czy przed rozpoczęciem studiów interesował się Pan/ Pani żywnością i żywieniem?

\begin{tabular}{llll}
\hline Yes / tak & 48,9 & 23.4 & \\
No / nie & 10,0 & 34.3 & $\mathbf{p}<0.0001$ \\
A little / trochę & 41.0 & 42.3 & \\
\hline
\end{tabular}


Has anyone ever suggested that you have pathological attitude towards food? / Czy ktoś sugerował Pani/Panu, że ma Pan/Pani patologiczny stosunek do jedzenia?

\begin{tabular}{llll}
\hline Yes / tak & 11.4 & 12.9 & \\
No/nie & 88.6 & 87.1 & $\mathrm{p}=\mathbf{0 , 6 1 5 8}$ \\
\hline
\end{tabular}

Are you concerned about your attitude towards food? / Czy jest Pan/Pani zaniepokojony swoim stosunkiem do jedzenia?

\begin{tabular}{llll}
\hline Yes / tak & 7.5 & 7.0 & \\
No / nie & 92.5 & 93.0 & $\mathrm{p}=\mathbf{0 , 8 4 5 9}$ \\
\hline
\end{tabular}

Have you been diagnosed with any mental disease or eating disorder? / Czy kiedyś rozpoznano u Pani/Pana chorobę psychiczną lub zaburzenie odżywiania?

\begin{tabular}{llll}
\hline Yes / tak & 1,7 & 0,5 & \\
No / nie & 98,3 & 99,5 & $\mathrm{p}=\mathbf{0 , 2 2 8 0}$ \\
\hline
\end{tabular}

What would you do if you heard a negative opinion about some food product or food ingredients? / Czy jeśli Pani/ Pan usłyszy negatywne opinie w mediach/ prasie naukowej odnośnie produktu, lub substancji wchodzącej w jego skład to:

\begin{tabular}{|c|c|c|c|}
\hline \multirow{3}{*}{$\begin{array}{l}\text { I would eliminate this product/ food } \\
\text { ingredients from my diet / eliminuje go } \\
\text { z diety } \\
\text { I would try avoid this product/ food } \\
\text { ingredients / staram się o unikać } \\
\text { I would do nothing / niczego nie robię }\end{array}$} & 5.3 & 1.0 & \multirow{3}{*}{$\mathrm{p}<0.0001$} \\
\hline & 86.0 & 83.0 & \\
\hline & 8.7 & 16,0 & \\
\hline \multicolumn{4}{|c|}{ Are you afraid of Genetically Modified Food? / Czy obawia się Pani/ Pan żywności modyfikowanej genetycznie? } \\
\hline Yes / tak & 44.0 & 43.3 & \multirow{3}{*}{$p=0,8135$} \\
\hline No / nie & 31.2 & 28.6 & \\
\hline I don't know / nie wiem & 24.8 & 28.1 & \\
\hline
\end{tabular}

In one study, the authors proposed a new way of diagnosing orthorexia and developed the Eating Habits Questionnaire [2]. In this research, the participants were undergraduates of the introductory psychology classes, introductory nutrition classes and upper level nutrition classes at Southeastern U.S. University. Since nutrition majors scored higher, the students of the introductory nutrition classes were considered to be more "orthorexic" than the students of the introductory psychology classes [2]. However, it is still necessary to conduct further research on groups with regard to ethnicity, age, culture, and professions. Establishing a cut-off point for screening purposes seems to be debatable because of the lack of consensus about the orthorexia concept [2].

Other studies conducted among students have shown that $68.6 \%$ of women and $43.2 \%$ of men were preoccupied with health food. There was no statistically significant difference observed between either women or men. Among those students, women achieved lower scores with regard to appearance evaluation and body satisfaction, but higher scores with regard to appearance orientation and overweight preoccupation [21].

\section{Conclusion}

1. Based on the BOT (Bratman Test for Orthorexia) results, the dietetics students have greater predispositions towards developing orthorexia than physiotherapy students. The dietetics students obtained significantly higher BOT results than the physiotherapy students.

2. Based on the results of the authors' questionnaire • Students of dietetics more frequently declared changes in their approach to food that influenced their eating behaviours when compared to the students of physiotherapy • The results showed that the dietetics students could have a greater tendency towards restricted food intake than the physiotherapy students.

\section{Appendices}

A critical point of the research is that the participants of both study groups were medical professionals. This may be the reason for high scores gained in the BOT. Further studies should be conducted also among subjects that are not medicine-related, for example, among the general public and/or individuals with specific eating habits, such as vegetarians. Finding new diagnostic criteria is very important because orthorexia - as well as anorexia - may lead to many somatic problems, and consequently to death. This study, although limited, underlines that dietetics students are more susceptible to orthorexia. Nevertheless, it is still necessary to create an adequate tool to evaluate this health problem. Our results should encourage other researchers to develop diagnostic criteria for orthorexia nervosa. 


\section{References}

1. Russell T, Stodd MD. Weathervane. Hawaii Med J. 2010; 69(5): 134.

2. Gleaves DH, Graham EC, Ambwani S. Measuring "Orthorexia": Development of the eating habits questionnaire. Int J Educ Psychol Assess. 2013; 12(2): 10-19.

3. Alvarenga MS, Martins KCT, Sato SVA et al. Orthorexianervosabehavior in a sample of Brazilian dietitians assessed by the Portuguese version of ORTO-15. Eat Weight Disord. 2012; 17(1): 29-35.

4. Catalina Zamora ML, BoteBonaechea B, García Sánchez $F$ et al. Orthorexia nervosa. A new eating behaviour disorder? Actas Esp Psiquiatr. 2005; 33(1): 66-68.

5. Bratman S, Knight D. Health food junkies. Orthorexia nervosa: overcoming the obsession with healthful eating. New York, Broadway Books, 2000.

6. Dittfeld A, Koszowska A, Fizia K et al. Ortoreksja - nowe zaburzenie odżywiania. Ann Acad Med Siles. 2013; 67(6): 393-399.

7. Mathieu J. What is orthorexia? J Am Diet Assoc. 2005; 105: 15101512.

8. Buddeberg-Fischer B, Bernet R, Schmid J et al. Relationship between disturber eating behaviour and other psychosomatic symptoms in adolescents. Psychoter Psychosom. 1996; 65(6): 913-326.

9. Park SW, Kim JY, Go GJ et al. Orthorexia nervosa with hyponatremia, subcutaneous emphysema, pneumomediastimum, pneumothorax, and pancytopenia. Electrolyte Blood Press. 2011; 9(1): 32-37.

10. Kinzl F J, Hauer K, Traweger Ch. Orthorexia nervosa in Dialecticians. Psychother and Psychosom. 2006; 75(6): 395-396.

11. Kędra E. Zaburzenia odżywiania - znak naszych czasów. Piel Zdr Publ. 2011; 2: 169-175.

12. Arusoğlu G, Kabakçi E, Köksal G et al. Orthorexia nervosa and adaptation of ORTO-11 into Turkish. Turk Psikiyatri Derg. 2008; 19(3): 283-291.

13. Saddichha S, Babu GN, Chandra P. Orthorexia nervosa presenting as prodrome of schizophrenia. Schizophr Res. 2012; 134(1): 110
14. Korinth A, Schiess S, Westenhoefer J .Eating behaviour and eating disorders in students of nutrition sciences. Public Health Nutr. 2010; 13(1): 32-37.

15. TulayBagciBosi A, Camur D, GulerCagatay G. Prevalence of orthorexia nervosa in resident medical doctors in the faculty of medicine (Ankara, Turkey). Appetite. 2007; 49(3): 661-666.

16. Eriksson L, Baigi A, Marklund B et al. Social physique anxiety and sociocultural attitudes toward appearance impact on orthorexia test in fitness participants. Scand J Med Sci Sports. 2008; 18(3): 389394.

17. Donini LM, Marsili D, Graziani MP et al. Orthorexia nervosa: a preliminary study with a proposal for diagnosis and an attempt to measure the dimension of the phenomenon. Eat Weight Disord. 2004; 9(2): 151-157.

18. Donini LM, Marsili D, Graziani MP et al. Orthorexia nervosa: Validation of a diagnosis questionnaire. Eat Weight Disord. 2005; 10(2): 28-32.

19. Moroze RM, Dunn TM, Craig Holland J et al. Microthinking About Micronutrients: A Case of Transition From Obsessions About Healthy Eating to Near-Fatal "Orthorexia Nervosa" and Proposed Diagnostic Criteria. Psychosomatics. 2015; 56(4): 397-403.

20. WHO Expert Consultation. Appropriate body-mass index for Asian populations and its implications for policy and intervention strategies. Lancet. 2004; 363(9403): 157-163.

21. Janas-Kozik M, Zejda J, Stochel M et al. Ortoreksja - nowe rozpoznanie? Psychiatr Pol, 2012; 46(3): 441-450.

22. Brytek-Matera A, Donini LM, Krupa M et al. Orthorexia nervosa and self-attitudinal aspects of body image in female and male university students. J Eat Disord. 2015; 24:32. 